\title{
Analyzing the Early Literacy Skills and Visual Motor Integration Levels of Kindergarten Students
}

\author{
Zeynep Dere ${ }^{1}$ \\ ${ }^{1}$ Medical School of Odemis, Ege University, Izmir, Turkey \\ Correspondence: Zeynep Dere, Medical School of Odemis, Ege University, Izmir, Turkey. E-mail: \\ zeynepder@gmail.com
}

Received: February 2, 2019

Accepted: February 26, 2019 Online Published: March 3, 2019

doi:10.5539/jel.v8n2p176

URL: https://doi.org/10.5539/jel.v8n2p176

\begin{abstract}
Early childhood education aims to support children's whole development and their school readiness. Children develop a knowledge about reading, writing and learning before elementary school. This knowledge is called early literacy and it's a key factor for school readiness. This study delves to investigate the early literacy skills of children and their visual motor integration. For this purpose, kindergarten students' level of early literacy skills and visual motor integration was determined and the correlation between the two was analyzed. Eighty children at the age of five (40 females and 40 males) attending kindergarten were purposively chosen. In the study, $38 \%$ of the participants in the kindergarten was in the inadequate level of early literacy skills and $62 \%$ was in the instructional level. Children in the instructional level also showed that they had better visual motor coordination skills as well. These children presented better visual motor coordination skills in the fine manipulative skills category, print awareness category, and expressive and receptive language skills category. It was seen that visual motor integration development is a valuable factor to supports kindergarten children's early literacy skills. For this reason, children's visual motor coordination skills should be taken into consideration and supported for their early literacy skills development.
\end{abstract}

Keywords: early literacy, kindergarten, visual motor development

\section{Introduction}

Early childhood education is for children from the ages three to six years old. It aims to support children's whole development and their school readiness. The learning goals of early childhood education described as knowledge (ideas, concepts, and vocabulary), skills (small and quick units of action), disposition (respond to particular circumstances), and feelings (Katz, 2003). It has been stated that early childhood education brings positive outcomes to a child's school life and future (Schweinhart et. al., 2005; Sparling, Ramey, \& Ramey 2007).

Visual perception is one person's ability to understand incoming visual information from their environment (Delcamp, 1983). Vision provides feedback to the motor system regarding spatial orientation, size, and letter formation. Difficulties in visual perceptual skills will result in difficulties discriminating between right and left, visual discrimination, visual-memory, and size and shape relationships. The visual skills foundation is established through the development of visual perceptual skills, functional visual skills and eye-hand coordination. Visual-motor skills involve fixation, focusing, and visual coordination abilities (Heeger, 1999). These skills are necessary to be able to visually attend to a task, and to be able to copy from a text or a whiteboard without the words doubling or jumping around on a page. Visual efficiency problems may affect a child's ability to see a visual symbol and/or clue. These lacks of information cause visual processing problems resulting difficulty in learning for children in kindergarten.

The basis of motor skills is established through the development of shoulder girdle stability, fine motor skills and eye-hand coordination. Visual motor integration is frequently defined as the ability to copy geometric shapes (Beery, 1982). This integration involves effective, efficient communication between the eyes and the hands, so that children are able to copy, draw or write. Effective coordination of the visual system and the motor system can be functional when the visual and motor skills foundations are well established (Memiş \& Ayvaz Sivri, 2016). Children who struggle to integrate or coordinate their visual systems and their motor systems may struggle with handwriting as well as with other school skills. Because one must be able to integrate the visual image of letters or shapes with the appropriate motor response (Smith, Allan, \& Pratt, 1996). 
Children might have varying levels of visual motor integration during kindergarten (Ercan, Ahmetoğlu, \& Aral, 2016; Duman, 2016). Identifying specific skills of visual motor integration process, educators and specialists have been able to predict children's success in elementary school. Studies indicate that children who has better visual motor integration skills in early years, are more likely to have better social behavior, executive functioning, ability to pay attention, following directions, and staying on task later in the school years (Grissmer et al., 2010). A child not being able to visually discriminate between shapes would not be able to learn to read as quickly and easily as a child displaying ease in discriminating between shapes and letters (Sperling \& Head, 2002).

Children are ready to learn naturally. Early childhood education aims to provide them with quality and valuable experiences. Through these experiences, children develop a knowledge about reading, writing and learning before elementary school. This knowledge is called early literacy (Neuman \& Roskos, 1998). Early literacy skills include vocabulary, print motivation, print awareness, letter knowledge, phonological awareness and narrative skills (Roskos, Christie, \& Richgels, 2003). These skills, including their relationship to one another, are critical in ensuring that children gain all of the preliminary skills and awareness they will need to become effective readers and writers (Rohde, 2015).

This study delves to investigate the early literacy skills of children and their visual motor integration. For this purpose, kindergarten students' level of early literacy skills and visual motor integration was determined and the correlation between the two was analyzed.

\section{Methods}

The model of this research was relational screening model. Relational screening model aims to describe past or present conditions as they appear. There is no attempt to alter or influence the conditions in the study. The relationships that are found through the screening are relatively interpreted rather than a cause-and-effect relationship (Karasar, 2018). Kindergarten students' level of early literacy skills and visual motor integration is described and comparatively analyzed.

\subsection{Population and Sampling}

The target population of the research is consisted of kindergarten students in Yozgat province, Turkey. The sample of the study was 80 children ( 40 girls and 40 boys) attending kindergarten classrooms. These students were at middle socioeconomic class located in the city centre of Yozgat. The method for chosing the samples was purposive sampling. Voluntary kindergarten students were selected to participate the study. Participants were randomly selected from seven kindergarten classrooms according to the gender equivalence.

\subsection{Data Collection Tools}

Beery Buktenica Developmental Visual-Motor Coordination Test was used in order to decide on children's visual motor integration levels. Early literacy assessment form was used to establish children's early literacy skills.

Beery Buktenica Developmental Visual-Motor Coordination Test was developed by Beery, Buktenica and Beery (2010). Demirler (2016) adapted this test to Turkish. This test prepared for all ages starts from page 4 for kindergarten children and the seventh question is for children at the age of five and above (Demirler \& Ar1, 2018). During visual motor coordination test, the maximum score of 30 can be achieved by a child.

Early literacy assessment form was developed by Koçak (2018) to determine and analyze the sub-dimensions of early literacy skills. Emerging literacy activities are compulsory educational activities for teachers to plan and apply. The definition and guidelines of the emerging literacy activities are presented for the teachers to plan and implement. Expected outcomes of the activities and targeted achievements are also listed. Early literacy assessment form was developed based on Ministry of Education's Early Childhood Education Program guideline (MoNE, 2013). There are three sub-categories related to visual motor integration in the form; fine motor skills, print awareness, and expressive and receptive language. Three-point Likert type scale was (inadequate, instructional, and independent levels) applied for the items.

\subsection{Data Collection and Analysis}

Data regarding to children's visual motor development was collected using Beery Buktenica Developmental Visual Motor Coordination Test. All the children participating the study took the test separately for visual motor coordination test. Each session was at the length of 30-35 minutes. Right answers were given one point and wrong answers were given zero. When a child made three consecutive mistakes, the test was completed. 
Data regarding to children's early literacy skills was collected using Early Literacy Assessment Form. Each child was observed twice in different days during free play time, emerging literacy activity time and Turkish activity time. Inter observer reliability was .90 for each child for 30 minutes. Total observation period for each child was 180 minutes. For the test items, one point was given for the inadequate level, two point was given for the instructional level, and three point was given for the independent level.

To analyze the data SPSS (22.0) was conducted. Mean scores and standard deviations were used to present the descriptive data. To analyze the significant differences in sub-dimensions of early literacy levels (inadequate and instructional), the t-Test was used. In the study, there were no children found at the independent level. To analyze the correlation between visual motor integration and early literacy sub-dimension (fine manipulative, print awareness, and expressive and receptive language) the Pearson Correlation Coefficient Test was conducted. $p<0.01$ level was measured as significant for the statistical analysis and interpretation.

\section{Results}

This study analyzed the early literacy and visual motor coordination levels of the kindergarten students.

Table 1. Early literacy levels of the kindergarten students

\begin{tabular}{lll}
\hline Early literacy skill levels & $f$ & $\%$ \\
\hline Inadequate level & 30 & 38 \\
Instructional level & 50 & 62 \\
Independent level & - & - \\
Total & 80 & 100 \\
\hline
\end{tabular}

Table 1 shows the early literacy levels of the kindergarten children. The study showed that 30 students (38\%) were in the inadequate early literacy level, and 50 students $(62 \%)$ were in the instructional level. It was also observed that none of the students were in the independent early literacy level. This result could be considered typical for kindergarten students because they are still in the process of learning.

Table 2. Early literacy skills of the kindergarten students

\begin{tabular}{lccccc}
\hline Sub-Dimension & $\mathrm{N}$ & $\bar{x}$ & $\mathrm{~S}$ & $\mathrm{t}$ & $p$ \\
\hline Fine manipulative & & & & & \\
Inadequate level & 32 & 1.31 & 0.37 & -2.63 & $.001^{*}$ \\
Instructional level & 48 & 2.15 & 0.45 & & \\
Total & 80 & & & & \\
Print awareness & & & & & $.001^{*}$ \\
Inadequate level & 30 & 1.34 & 0.39 & -2.60 & \\
Instructional level & 50 & 1.92 & 0.42 & & $.000^{*}$ \\
Total & 80 & & & & \\
Expressive and receptive language & & & & & \\
Inadequate level & 28 & 1.44 & 0.35 & -2.59 & \\
Instructional level & 52 & 1.87 & 0.43 & & \\
Total & 80 & & & & \\
\hline
\end{tabular}

Note. $\mathrm{p}<0.01$.

Table 2 presents the sub-dimensions of early literacy skills of the kindergarten children. The arithmetic mean score of the fine manipulative skills of the inadequate level students was found as 1.31 , and 2.15 for the instructional level. Instructional level students had significantly $(p<0.01)$ higher fine manipulative skills according to inadequate level children. The arithmetic mean score of the print awareness skills of the inadequate level students was found as 1.34 , and 1.92 for the instructional level. Instructional level students had significantly $(p<0.01)$ greater print awareness skills according to inadequate level students. In addition, the arithmetic mean score of the expressive and receptive language skills of the inadequate level students was 1.44, and 1.87 for the instructional level in the study. Instructional level students had significantly $(p<0.01)$ higher expressive and receptive language skills when compared to inadequate level children.

These results have showed that children with better early literacy skills. These children also had better achievements in all three sub-dimensions of early literacy (fine manipulative, print awareness, and expressive 
and receptive language). The results of t-Tests also showed that kindergarten students' skill levels were significantly different in all groups of sub-dimensions.

Table 3. Early literacy skills and visual motor coordination of the kindergarten students

\begin{tabular}{llllll}
\hline Visual motor coordination & $\mathrm{N}$ & $\bar{x}$ & $\mathrm{~S}$ & $\mathrm{t}$ & $p$ \\
\hline Inadequate level & 30 & 13.23 & 2.43 & -3.15 & $.001^{*}$ \\
Instructional level & 50 & 16.47 & 2.17 & & \\
Total & 80 & & & & \\
\hline
\end{tabular}

Note. $\mathrm{p}<0.01$

Table 3 shows the visual motor coordination of the kindergarten children when analyzed in terms of early literacy skill levels. Inadequate level children's arithmetic mean was found as 13.23 for visual motor coordination. This measurement was 16.47 for the instructional level children. The visual motor coordination of the instructional level children is significantly better $(p<0.01)$ according to inadequate level students.

Table 4. Pearson correlation scores of early literacy skills and visual motor coordination

\begin{tabular}{|c|c|c|c|}
\hline & Fine manipulative & Print awareness & Expressive and receptive language \\
\hline Visual motor coordination & $.86^{*}$ & $.82 *$ & $.47 *$ \\
\hline
\end{tabular}

Table 4 shows the Pearson Correlation Coefficient values of early literacy sub-dimension skills (fine manipulative, print awareness, and expressive, and receptive language) and visual motor coordination. The analysis indicated that there was significant correlation between visual motor coordination and fine manipulative skills (.86), and visual motor coordination and print awareness skills (.82). Results presented that there was moderate level (.47) correlation between visual motor coordination and expressive and receptive language skills. According to these results, two of the children's early literacy skills (fine manipulative, and print awareness) had significant correlation with the visual motor coordination skills. One of the early literacy skills, expressive and receptive language, showed moderate level of correlation. It can be stated that expressive and receptive language skills depend on more learning experiences.

\section{Conclusion and Discussion}

The purpose of this study was to examine the early literacy skills of five years old kindergarten children and their visual motor integration. Whether there was a correlation between early literacy skills and visual motor integration was also examined. It has been found that $38 \%$ of the participants in the study were in the inadequate level and $62 \%$ were in the instructional level of early literacy skills. The children in the instructional level had greater values for visual motor coordination skills as well. These children presented better visual motor coordination skills in the fine manipulative skills category, print awareness category, and expressive and receptive language skills category. The Pearson Correlation Coefficient value was significant when it comes to fine manipulative skills and print awareness regarding to visual motor coordination. However, this value was moderate in terms of expressive and receptive language skills.

Other researchers found results supporting most of the findings of this study. In their research Erdoğan, Özen Altınkaynak and Erdoğan (2013) found that kindergarten teachers gave priority to teach fine manipulative skills. These activities naturally support visual motor coordination as well. On the other hand, it has been stated that educational activities supporting phonological awareness of children were weak (Koçak, 2018; Patterson, 2002). However, studies showed that there is a very strong correlation between phonological awareness and print awareness (Ferah, 2001; Sperling \& Head, 2002; Memiş \& Ayvaz Sivri, 2016). Visual motor coordination is one of the key aspects of print awareness and reading (Kavale \& Forness, 2000; Thompson, 1975; Arıkök, 2001). Supporting these findings, this study showed significant relation for print awareness and visual motor coordination; and yet, moderate relation for expressive and receptive language skills.

According to the gained outcomes, the visual motor coordination skills are valuable elements to encourage kindergarten children's early literacy skills. For children's later success in school, early literacy skills are important factors (Delcamp, 1983; Koçak, 2018). As a conclusion, children's visual motor coordination skills should be taken into consideration and supported for their early literacy skills development. 


\section{References}

Arıkök, İ. (2001). Beş-altı yaş çocuklarında görsel algı eğitiminin okuma olgunluğuna olan etkisinin incelenmesi. Yayımlanmamış yüksek lisans tezi, Gazi Üniversitesi, Ankara.

Beery, K. E. (1982). Revised administration, scoring, and teaching manual for the Developmental Test of Visual-Motor Integration. Cleveland, OH: Modern Curriculum Press.

Beery, K., Buktenica, N., \& Beery, N. (2010). Beery-Buktenica Developmental Test of Visual-Motor Integration, Sixth Edition (BEERYTM VMI). Pearson.

Delcamp, L. N. (1983). Relationships among conservation abilities, auditory and visual perception skills and school achievement of first grade students. Unpublished master's thesis, University of Florida.

Demirler, Ö. F. (2016). 36-79 ayllk çocuklar üzerinde uygulanan Beery-Buktenika gelişimsel görsel motor koordinasyon testinin geçerlik ve güvenirlik çalışması. Yayımlanmamış yüksek lisans tezi, Okan Üniversitesi, Istanbul.

Demirler, Ö. F., \& Arı, M. (2018). Beery-Buktenika gelişimsel görsel motor koordinasyon testinin 36-79 aylık çocuklara uyarlanması. Turkish Journal of Primary Education, 3(1), 1-18.

Duman, G. (2016). Okul öncesi eğitimde beden eğitimi ve oyun. Ĕgiten: Ankara.

Ercan, Z. G., Ahmetoğlu, E., \& Aral, N. (2016). Görsel alg1 eğitiminin beş-altı yaş grubu çocukların görsel motor bütünlük becerilerine etkisi. The Journal of Academic Social Science Studies, 48, 319-332. https://doi.org/10.9761/JASSS3506

Erdoğan, T., Özen, A., \& Erdoğan. (2013). Okul öncesi öğretmenlerinin okuma-yazmaya hazırlığa yönelik yaptıkları çalışmaların incelenmesi. İlköğretim Online, 12, 4.

Ferah, A. (2001). Her yönüyle Türkçe ilkokuma yazma. İstanbul: M.E.B Yayınları.

Grissmer, D., Grimm, K. J., Aiyer, S. M., Murrah, W. M., \& Steele, J. S. (2010). Fine motor skills and executive function both contribute to kindergarten achievement. Author Manuscript, 83(4), 1229-1244. https://doi.org/10.1111/j.1467-8624.2012.01768.x

Heeger, D. J. (1999). Linking visual perception with human brain activity. Current Opinion in Neurobology, 9 , 474-479. https://doi.org/10.1016/S0959-4388(99)80071-3

Karasar, N. (2018). Bilimsel araştırma yöntemi. Nobel: Ankara.

Katz, R. (2003). Life expectancy for children with cerebral palsy and mental retardation: Implications for life care planning. Neuro Rehabilitation, 18, 261-270.

Kavale, K., \& Forness, S. (2000). Auditory and visual perception processes and reading ability: a quantitative reanalysis and historical interpretation. Learning Disability Quarterly, 23, 253-270. https://doi.org/10.2307/1511348

Koçak, M. (2018). Okul öncesi eğitimde kullanılan okuma yazmaya hazırlı etkinlik planlarının incelenmesi. Yayımlanmamış yüksek lisans tezi, Gazi Üniversitesi, Ankara.

Memiş, A., \& Ayvaz, S. D. (2016). The analysis of reading skills and visual perception levels of first grade Turkish students. Journal of Education and Training Studies, 4(8), Redfame Pub. https://doi.org/10.11114/jets.v4i8.1663

MoNE. (2013). Early childhood education program. Ministry of Education, Ankara.

Neuman, S. B., \& Roskos, K. A. (1998). Children achieving: best practices in early literacy. International Reading Association, Newark, DE.

Patterson, J. R. (2002). Teacher Beliefs and Practices in Preschool Literacy Instruction. Unpublished Doctoral Dissertation, University of Illinois at Chicago.

Rohde, L. (2015). The comprehensive emergent literacy model: early literacy in context. Research Article, 23. https://doi.org/10.1177/2158244015577664

Roskos, K. A., Christie, J. F., \& Richgels, D. J. (2003). The essentials of early literacy instruction. Teaching and Learning About Early Literacy, 52-60.

Schweinhart, L. J., Montie, J., Xiang, Z., Barnett, W. S., Belfield, C. R., \& Nores, M. (2005). Lifetime effects: The High/Scope Perry Preschool study through age 40. Monographs of the High/Scope Educational Research Foundation, 14. Ypsilanti, MI: High/Scope Press 
Smith, J. C., Allen, A. S., \& Pratt, P. N. (1996). Occupational therapy for children. Mosby.

Sparling, J., Ramey, C. T., \& Ramey, S. L. (2007). The Abecedarian experience. In M. E. Young (Ed.), Early Child Development-From measurement to action: A priority for growth and equity (pp. 81-99). Washington, DC: The World Bank.

Sperling, R., \& Head, D. (2002). Reading attitudes and literacy skills in prekindergarten and kindergarten children. Early Childhood Education, 29(4), 233-238. https://doi.org/10.1023/A:1015129623552

Thompson, L. J. J. (1975). The relationship of visual perception to reading achievement and the effects of two types of visual perceptual training on reading achievement in the first-grade year. Unpublished doctoral dissertation, University of Southern Mississippi.

\section{Copyrights}

Copyright for this article is retained by the author, with first publication rights granted to the journal.

This is an open-access article distributed under the terms and conditions of the Creative Commons Attribution license (http://creativecommons.org/licenses/by/4.0/). 